\title{
PROGRAM INDUKSI DAN ORIENTASI KARYAWAN BARU SECARA VIRTUAL DI MASA PANDEMI COVID-19 PT TELKOM INDONESIA (PERSERO) TBK
}

\author{
Taufiq Dwi Apriyanto ${ }^{1}$
}

\begin{abstract}
COVID-19 has potential to change the culture. The COVID-19 crisis has forced virtual working to become the main method of doing business in the modern due to social restrictions such as PT Telkom Indonesia. Management in PT Telkom Indonesia is faced with the problem of how to keep the orientation program during the COVID-19 pandemic because the company really needs these new employees so that business processes can continue to run smoothly. This virtual orientation program does not reduce orientation values, participants can still survive, thus adding many new experiences because all assignments are made online. The point is that participants can still carry out their normal activities because technology is getting more sophisticated. This paper uses a qualitative research approach. Data collection techniques are made in two ways, field studies and literature studies. Field studies were made by interview. Orientation program are not easy because participants and companies only meet virtually. Companies should overprepare. Companies can make detailed guidelines for the implementation of the Orientation Program, make a priority scale, and always provide feedback as soon as possible on the final result. The advantages of this virtual induction program are (1) the company can save costs; (2) shorter event time; (3) safe from COVID-19 (4) the application of New Technology based on Virtual Meeting. The weakness of this virtual orientation program is (1) lack of control from mentors; (2) minimal experience for employees because material that should require meeting physically is not well conveyed, one of which is increasing collaboration between teams.
\end{abstract}

Keywords: COVID-19; Orientation Program; Telkom; Virtual.

\section{PENDAHULUAN}

Virus korona ketiga yang menyerang manusia abad ini muncul pada Desember 2019. Mirip dengan sindrom infeksi pernafasan akut (SARS-CoV) dan sindrom infeksi pernafasan Timur Tengah (MERS-CoV), pasien menunjukkan gejala demam, batuk kering, sesak napas, dan leukopenia (Gralinski and Menachery, 2020). Selain berdampak mematikan kehidupan manusia, COVID-19 memiliki potensi mengubah peradaban, baik secara positif maupun negatif. COVID-19 memaksa umat manusia untuk merenggangkan

\footnotetext{
${ }^{1}$ Fakultas Ilmu Administrasi, Universitas Indonesia
} 
relasi dan interaksi sosial. Umat manusia terpaksa menghindari kerumunan. Aktivitas beribadah, bekerja serta belajar dari rumah. COVID-19 juga mengganggu supply chain, menghambat produksi sehingga memperlambat pertumbuhan ekonomi, tidak hanya di China, Amerika Serikat (AS), India atau Indonesia, tetapi juga dunia secara keseluruhan.

Boston Consulting Group menemukan bahwa program induksi memiliki dampak bisnis tertinggi kedua dari 22 praktik SDM yang disajikan dalam paper mereka untuk membawa praktik SDM ke tingkat berikutnya (Abramo et al., 2013). Sebelum pandemi COVID-19 merebak, mungkin sebagian besar perusahaan masih menerapkan program induksi dan orientasi karyawan baru secara formal yaitu dilakukan onsite di dalam kantor maupun secara outbond di tempat tertentu. Namun hal ini berbanding terbalik ketika pandemi COVID-19 menyebar secara cepat di dunia. Perusahaan harus segera menyesuaikan program orientasi mereka ke format virtual. Meskipun sebagian besar transisi ini sangat mendadak, pembelajaran dan praktik terbaik dari perubahan ini dapat digunakan untuk memahami cara mempertahankan program orientasi virtual dalam jangka panjang. Perusahaan IT lah yang paling paham mengenai teknologi, jadi tidak mengherankan jika banyak perusahaan di industri IT ini telah beralih ke program induksi virtual secara efektif selama krisis COVID-19. Perusahaan-perusahaan ini sudah cenderung memanfaatkan teknologi untuk merampingkan dan mengotomatiskan praktik bisnis mereka. Mereka sering kali mengetahui bagaimana teknologi dapat mengubah cara orang hidup dan bekerja. Tampaknya beberapa dari perusahaan IT ini juga bersedia berbagi pembelajaran mereka tentang orientasi virtual. Misalnya, LinkedIn telah membagikan bagaimana perusahaan telah mengubah pengalaman orientasi mereka untuk karyawan baru setelah krisis COVID-19 (Anderson, 2020). Memahami cara secara efektif merekrut karyawan baru secara virtual tidak hanya akan membantu perusahaan berkembang selama krisis COVID-19 tetapi juga akan menjadi semakin relevan karena semakin banyak perusahaan dan individu memilih untuk bekerja dari jarak jauh dengan berkelanjutan.

Krisis COVID-19 telah memaksa virtual working menjadi metode utama untuk menjalankan bisnis di dunia modern karena pembatasan sosial. Tak terkecuali perusahaan BUMN plat merah milik pemerintah, yaitu PT Telkom Indonesia. Telkom saat ini sangat berpegang teguh pada core values dari Kementrian BUMN, yaitu AKHLAK (Amanah, Kompeten, Harmonis, Loyal, Adaptif, Kolaboratif) yang mengandung spirit kebersamaan 
agar kualitas customer experience dalam perusahaan tetap terjaga. Dalam menciptakan customer experience yang berkualitas, tentunya diperlukan pengembangan strategi talent yang berkualitas juga. Pengembangan strategi talent terdiri dari rekrutmen, seleksi, hiring, pelatihan dan pengembangan, hingga manajemen kinerja karyawan. Induksi adalah bagian dari proses hiring karyawan.

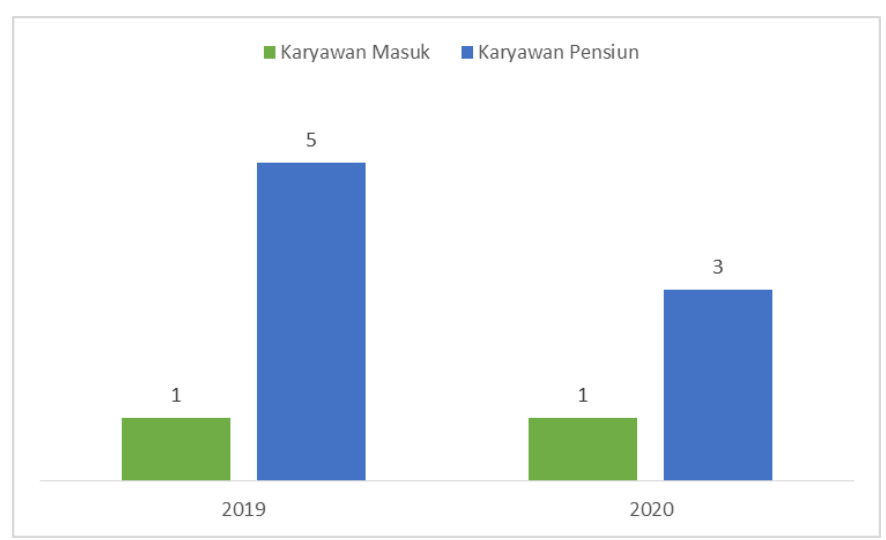

\section{Gambar 1 Perbandingan Karyawan Masuk dan Karyawan Pensiun}

Sekitar kurang lebih seribu karyawan PT Telkom pensiun setiap tahun. Data yang diperoleh dari database kepegawaian Bidang Human Capital (Gambar 1), pada tahun 2019 perbandingan karyawan masuk dan karyawan pensiun adalah besarnya satu dibanding lima. Kemudian untuk tahun 2020 sendiri, perbandingan antara karyawan masuk dan karyawan pensiun adalah sebesar satu dibanding tiga. Hal ini dapat diartikan bahwa tiga orang karyawan yang pensiun, akan digantikan oleh satu orang karyawan yang baru masuk. PT Telkom dalam 5 tahun terakhir memang sangat concern terhadap rekrutmen karyawan baru untuk menggantikan karyawan yang telah pensiun. Pada tahun 2020 kemarin, jumlah karyawan milenial hanya sebesar 20\% saja dari total karyawan keseluruhan. PT Telkom memiliki harapan besar kepada karyawan milenial ini karena mereka merupakan generasi penerus perusahaan di masa mendatang.

Pada awal tahun 2020 yang lalu, PT Telkom telah mengumumkan hasil seleksi calon karyawan baru untuk Great People Trainee Program Batch XII. Pandemi COVID19 yang merebak di Indonesia pada bulan Maret 2020, mengakibatkan program Induksi bagi calon karyawan baru ini sempat tertunda. Di sisi lain, perusahaan sudah sangat membutuhkan para karyawan baru ini agar bisnis proses tetap berjalan lancar. Manajemen dihadapkan pada permasalahan bagaimana cara agar program Induksi dan Orientasi di masa pandemi COVID-19 ini tetap berjalan lancar. Banyak proses eksisting yang harus diubah untuk menghadapi perubahan ini, seperti yang telah dilakukan oleh PT Telkom, 
yaitu melakukan program Induksi dan Orientasi karyawan baru secara virtual. Tujuan dari paper ini adalah untuk memberikan gambaran bagaimana program Induksi dan Orientasi karyawan baru secara virtual yang telah dilakukan oleh PT Telkom pada kuartal tiga tahun 2020 yang lalu.

\section{Tinjauan Teoritis}

Virtual workplaces atau aturan di mana karyawan bekerja secara jarak jauh satu dengan yang lain, tidak hanya menjadi kenyataan dalam lanskap bisnis saat ini, tetapi akan menjadi lebih umum di masa depan (Cascio, 2000). Seiring dengan meningkatnya globalisasi dan kecanggihan pengelolaan bisnis, virtual workplaces ini akan menjadi lebih umum bagi seorang individu dan tim yang tersebar di seluruh dunia untuk bekerja secara langsung satu sama lain, menggunakan teknologi untuk mengkomunikasikan dan mengoordinasikan pekerjaan mereka (Ahuja \& Carley, 1999). Bentuk dan kualitas produk teknologi yang memfasilitasinya terus meningkat, hal ini akan memperluas kemampuan sebuah tim untuk saling mengoperasikan dari jarak jauh (Fulk \& DeSanctis, 1995).

Selain pengaturan kerja jarak jauh yang memang sudah direncanakan suatu perusahaan, ternyata ada saat di mana kejadian tak terduga dapat memaksa sebuah perusahaan untuk melakukan pendekatan kerja jarak jauh kepada karyawan mereka. Misalnya, setelah krisis COVID-19 yang menggemparkan seluruh dunia awal tahun 2020 yang lalu, sebagian besar tenaga kerja di seluruh dunia harus segera beralih ke pengaturan kerja jarak jauh berdasarkan peraturan setempat. Diperkirakan hampir setengah dari angkatan kerja bekerja dari jarak jauh di beberapa titik selama krisis COVID-19 (Brynjolfsson et al., 2020). Meskipun bekerja dari jarak jauh memiliki banyak dampak pada cara individu dan tim ketika bekerja, dampak signifikan lainnya adalah bagaimana para karyawan baru yang baru direkrut juga diperkenalkan ke dalam organisasi mereka (Elset, 2018; Gruman \& Saks, 2018). Dampak jangka panjang yang baik dari situasi ini mungkin bahwa lebih banyak perusahaan dan individu akan mulai menemukan keuntungan dari pekerjaan jarak jauh, dan kemudian memilih untuk tetap menggunakan cara baru mereka untuk bekerja sama (Brynjolfsson et al., 2020).

Menurut Society for Human Resources Management (SHRM), program orientasi karyawan (juga dikenal sebagai sosialisasi organisasi) adalah "proses membantu karyawan baru menyesuaikan diri dengan aspek sosial dan kinerja dari pekerjaan baru mereka dengan cepat dan lancar, dan mempelajari sikap, pengetahuan, keterampilan, dan 
perilaku yang diperlukan untuk berfungsi secara efektif dalam organisasi.” Di dalam praktiknya, program orientasi akan beragam, baik ditinjau dari jenisnya maupun lamanya orientasi. Ada orientasi yang hanya sampai beberapa hari saja, tetapi ada juga orientasi yang sampai dengan berminggu-minggu bahkan ada yang sampai dengan satu tahun. Hal ini sangat terkait dengan derajat kompleksitas jenis pekerjaan dan kualifikasi karyawan (Nugraha, 2005).

Saat ini karyawan bergantung pada teknologi untuk melakukan pekerjaan mereka, perusahaan harus mempertimbangkan bagaimana orientasi dipengaruhi oleh tren ini dan bagaimana mereka dapat menggunakan teknologi untuk secara positif mengubah prosedur orientasi (Flanigan \& Waldeck, 2004). Adanya kemajuan teknologi, menjadi peluang besar tentang bagaimana pengusaha dapat memanfaatkannya untuk mendukung karyawan baru mereka selama orientasi berlangsung (Gruman \& Saks, 2018). Faktanya, teknologi telah digunakan dalam program orientasi untuk beberapa waktu sekarang, biasanya sebagai bagian dari model hybrid (Cascio, 2000).

Krisis COVID-19 telah menggambarkan bagaimana konsep kerja jarak jauh dan program orientasi karyawan baru sangat berkaitan erat (Brynjolfsson et al., 2020). Perusahaan IT di luar negeri sana memang berada di garis depan dalam virtual workplaces ini karena banyak dari mereka sudah menggunakan mekanisme untuk bekerja secara virtual. Virtual workplaces akan membantu menjaga karyawan lebih engaged dan produktif, baik dalam pengaturan kerja jarak jauh yang direncanakan maupun selama masa pandemi COVID-19 berlangsung.

\section{METODE PENELITIAN}

Paper ini menggunakan pendekatan penelitian kualitatif. Menurut Bogdan dan Taylor (1973) penelitian kualitatif dapat didefinisikan sebagai prosedur penelitian yang menghasilkan data deskriptif berupa kata-kata tertulis atau lisan dari orang-orang yang berperilaku yang dapat diamati. Paper ini ingin menggambarkan atau mendeskripsikan tentang program induksi dan orientasi bagi Karyawan Baru yang pernah dilakukan oleh PT. Telkom Indonesia serta membandingkan program ini dari sebelum dan sesudah pandemi COVID-19 melanda.

Teknik pengumpulan data dilakukan melalui dua cara, yaitu studi lapangan dan studi kepustakaan. Studi lapangan yang dimaksud adalah berupa data primer dengan 
teknik wawancara dari seorang informan. Kemudian yang kedua adalah studi kepustakaan, adalah teknik pengumpulan data yang dilakukan dengan mempelajari, mengutip, dan memasuki berbagai informasi dan teori yang dibutuhkan untuk mengungkap masalah yang dijadikan obyek penelitian dan untuk menyusun konsep penelitian. Informan yang dipilih adalah salah satu karyawan baru Great People Trainee Program Batch XII yang baru saja menyelesaikan induksi/orientasi virtual dan salah satu officer di bagian Talent \& Prohire Acquisition Operation PT Telkom Indonesia.

\section{HASIL DAN PEMBAHASAN}

\section{A. Induksi dan Orientasi PT Telkom Indonesia Sebelum Pandemi COVID-19}

Setelah dinyatakan lulus sebagai calon Karyawan melalui rangkaian seleksi, calon Karyawan memasuki tahapan orientasi dasar dengan rangkaian aktifitas meliputi pembinaan mental, In Class Training, On the Job Training (OJT), dan Karyawan Dalam Masa Percobaan. Penjelasan tahapan ini akan diuraikan di bawah:

1. Pembinaan Mental

Dilakukan selama 2 minggu di Pusat Pendidikan Pengetahuan Militer Umum TNI AD Cimahi, Jawa Barat. Materi yang diajarkan adalah tentang perilaku kedisiplinan diri, kerjasama, survival, dan wawasan kebangsaan.

\section{In Class Training}

Program In Class Training adalah program pengenalan bisnis budaya perusahaan dan diselenggarakan dengan durasi waktu selama maksimal 2 (dua) minggu yang dilakukan di Telkom Corporate University Center (TCUC) Bandung.

3. On the Job Training (OJT)

OJT dilakukan dengan ketentuan sebagai berikut:

a. Peserta didampingi oleh mentor yang ditunjuk oleh unit TCUC.

b. Peserta diberi penugasan secara rotasi ke minimal 2 (dua) unit kerja berbeda selama maksimum 2 (dua) bulan dan diberikan penugasan berbasis project yang akan dievaluasi sekurang-kurangnya 1 (satu) kali setiap bulan.

c. Selama tahapan OJT, peserta rekrut tidak diberikan hak pelaksanaan izin/cuti, namun demikian SGM Human Capital Business Partner diberikan kewenangan untuk mengeluarkan izin/cuti dengan alasan khusus. Pelaksanaan 
OJT diperpanjang sesuai dengan masa pelaksanaan izin/cuti yang bersangkutan.

d. Selama tahapan OJT, peserta diberikan uang saku, uang transportasi ke tempat penugasan, email, akses portal, dan fasilitas kerja IT yang nilainya ditetapkan oleh SGM Human Capital Business Partner.

e. Evaluasi selama masa OJT dilakukan secara berkala yang diutamakan untuk mengevaluasi aspek-aspek sebagai berikut:

i. $\quad$ Karakter (Integrity, Enthusiasm, Loyalty) dan 3S (Solid, Speed, Smart) serta Attitude yang bersangkutan;

ii. Penguasaan kompetensi fungsional/teknis, pencapaian dalam assignment/project, kebugaran dalam setiap penugasan serta rekomendasi dari coach/mentor yang ditunjuk.

iii. Hasil evaluasi dalam tahapan OJT merupakan dasar pertimbangan bagi peserta untuk diangkat menjadi Karyawan Dalam Masa Percobaan (KDMP).

4. Karyawan Dalam Masa Percobaan (KDMP)

a. Peserta rekrutmen yang telah mengikuti OJT kemudian diangkat menjadi Karyawan Dalam Masa Percobaan (KDMP) untuk selanjutnya mengikuti program onboarding dengan menandatangani kesediaan untuk mematuhi ketentuan yang berlaku.

b. Selama masa KDMP peserta ditempatkan pada posisi yang akan dituju atau pada posisi lain yang memiliki fungsi yang bersesuaian hingga maksimal 3 (tiga) bulan.

c. Pada akhir masa KDMP, peserta akan melalui proses evaluasi yang hasilnya menjadi dasar dalam keputusan pengangkatan Karyawan Tetap dengan mempertimbangkan pemenuhan persyaratan dan kualifikasi yang ditetapkan serta rekomendasi dari manajer lini yang terkait.

d. Pengangkatan sebagai Karyawan Tetap merupakan tahapan akhir dalam proses recruitment di mana peserta menandatangani perjanjian kerja dengan Perusahaan yang diwakili oleh pejabat yang berwenang.

e. Keputusan pengangkatan Karyawan Tetap ditandai dengan diterbitkannya surat keputusan pengangkatan yang sekurangkurangnya mencantumkan nama, 
NIK, tanggal mulai berlaku, status Karyawan, nama posisi/jabatan, level posisi/jabatan, lokasi kerja, gaji dasar, dan lainnya sesuai tata naskah surat keputusan. Entry level untuk peserta rekrutmen yang diangkat sebagai Karyawan Tetap akan menempati BOD-6.

\section{B. Induksi dan Orientasi PT Telkom Indonesia Setelah Pandemi COVID-19}

Tahapan masa orientasi karyawan baru setelah pandemi COVID-19 sebenarnya hampir sama dengan sebelum pandemi. Yang membedakan hanyalah peniadaan aktivitas pembinaan mental yang dilakukan bersama TNI AD serta pelaksanaan In Class Training dilakukan melalui virtual meeting. Untuk On the Job Training (OJT) dan tahapan Karyawan Dalam Masa Percobaan masih dilaksanakan.

\section{Tabel 1 Perbandingan Orientasi Karyawan Baru Sebelum dan Sesudah Pandemi}

\begin{tabular}{|c|c|c|c|}
\hline No & Pembeda & Orientasi Sebelum Pandemi & Orientasi Setelah Pandemi \\
\hline 1 & $\begin{array}{l}\text { Tahapan } \\
\text { Pelaksanaan }\end{array}$ & $\begin{array}{l}\text { - Pembinaan Mental } \\
\text { - In Class Training } \\
\text { - On Job Training } \\
\text { - Karyawan Dalam Masa } \\
\text { Percobaan }\end{array}$ & $\begin{array}{l}\text { - Virtual Training } \\
\text { - On Job Training } \\
\text { - Karyawan Dalam Masa } \\
\text { Percobaan } \\
\text { - Pembinaan Mental } \\
\text { (menunggu pandemi } \\
\text { COVID-19 berakhir) }\end{array}$ \\
\hline 2 & $\begin{array}{l}\text { Lokasi } \\
\text { Pelaksanaan }\end{array}$ & $\begin{array}{l}\text { - } \text { Pembinaan Mental : } \\
\text { Pusdikhub TNI AD Cimahi } \\
\text { - In Class Training : Telkom } \\
\text { Corporate University Center } \\
\text { Bandung } \\
\text { - On Job Training : Kantor } \\
\text { Wilayah Telekomunikasi } \\
\text { seluruh Indonesia } \\
\text { - Karyawan Dalam Masa } \\
\text { Percobaan : Kantor Telkom } \\
\text { Seluruh Indonesia }\end{array}$ & $\begin{array}{l}\text { - Virtual Training : Zoom } \\
\text { dari rumah masing-masing } \\
\text { - On Job Training : Kantor } \\
\text { Wilayah Telekomunikasi } \\
\text { seluruh Indonesia } \\
\text { - Karyawan Dalam Masa } \\
\text { Percobaan : Kantor Telkom } \\
\text { Seluruh Indonesia } \\
\text { - Pembinaan Mental } \\
\text { (menunggu COVID } \\
\text { berakhir) : Pusdikhub TNI } \\
\text { AD Cimahi }\end{array}$ \\
\hline 3 & $\begin{array}{l}\text { Waktu } \\
\text { Pelaksanaan }\end{array}$ & $\begin{array}{l}\text { Ada waktu tambahan untuk } \\
\text { melakukan perpindahan posisi } \\
\text { karyawan, dari lokasi in class } \\
\text { training ke lokasi On Job } \\
\text { Training. }\end{array}$ & $\begin{array}{l}\text { - Waktu lebih singkat, karena } \\
\text { tidak membutuhkan waktu } \\
\text { tambahan untuk perpindahan } \\
\text { orang (dikumpulkan di } \\
\text { bandung, kemudian disebar } \\
\text { saat OJT. } \\
\text { - Waktu mentoring lebih } \\
\text { sedikit, hanya dilakukan } \\
\text { selama 2-4 jam, setelah itu } \\
\text { diberikan tugas tanpa diawasi } \\
\text { mentor langsung. }\end{array}$ \\
\hline
\end{tabular}




\begin{tabular}{|c|l|l|l|}
\hline \hline No & \multicolumn{1}{|c|}{ Pembeda } & Orientasi Sebelum Pandemi & Orientasi Setelah Pandemi \\
\hline 4 & Biaya & $\begin{array}{l}\text { Biaya yang dikeluarkan lebih } \\
\text { besar. }\end{array}$ & $\begin{array}{l}\text { Biaya yang dikeluarkan lebih } \\
\text { sedikit karena dilakukan } \\
\text { melalui Virtual Meeting. }\end{array}$ \\
\hline
\end{tabular}

Sumber: Olahan data penulis

Tabel 2 Gambaran Pelaksanaan Orientasi Karyawan Baru di Masa Pandemi Great People Trainee Program Batch XII PT Telkom Indonesia

\begin{tabular}{|l|c|c|}
\hline \multicolumn{1}{|c|}{ Acara } & Tanggal Pelaksanaan & Keterangan \\
\hline Persiapan & 2 Agustus 2020 & Terlaksana \\
\hline Pembukaan & 3 Agustus 2020 & Terlaksana \\
\hline Bintal Online & 3 - 8 Agustus 2020 & Terlaksana \\
\hline In Class Training & 10 Agustus - 11 September 2020 & Terlaksana \\
\hline On The Job Training & 14 September - 9 Oktober 2020 & Terlaksana \\
\hline Bintal Onsite & 12 Oktober - 28 Oktober 2020 & Tidak Terlaksana \\
\hline Karyawan Dalam Masa Percobaan & 30 Oktober 2020 & Terlaksana \\
\hline
\end{tabular}

Sumber: Olahan data penulis

Tabel 2 di atas menjelaskan bagaimana gambaran pelaksanaan orientasi karyawan baru di masa pandemi. Hanya satu acara yang tidak terlaksana, yaitu pembinaan mental bersama TNI AD secara onsite. Acara ini mengalami penundaan karena pandemi COVID-19 masih merebak.

\section{Pembahasan}

Menurut Muh. Insan yang merupakan salah satu officer di bagian Talent \& Prohire Acquisition Operation PT Telkom Indonesia, program induksi dan orientasi secara virtual memiliki kelebihan dan kekurangan. Kelebihan dari program virtual ini adalah seperti:

- Bisa menghemat biaya yang dikeluarkan

Biaya yang dikeluarkan lebih sedikit karena penyelenggara tidak perlu membayar biaya yang menghabiskan banyak uang, salah satunya adalah konsumsi peserta.

- Waktu penyelenggaraan lebih pendek

Kegiatan dilakukan secara virtual dari lokasi masing-masing sehingga penyelenggara tidak perlu ada waktu tambahan dalam hal perpindahan tempat.

- Aman dari COVID-19

Kegiatan dilakukan secara virtual dan menghindari kontak langsung antar peserta program.

- Penerapan Teknologi Baru berbasis Virtual Meeting

Pandemi COVID-19 mengakibatkan perusahaan dipaksa untuk menjadi lebih agile dalam penerapan teknologi baru. 
Program induksi dan orientasi juga memiliki kekurangan, akan dijelaskan sebagai berikut :

- Kurangnya kontrol dari mentor

Program yang dilakukan secara virtual membuat mentor tidak bisa langsung mengawasi apa yang dikerjakan oleh para peserta.

- Minim experience bagi karyawan

Materi yang seharusnya memerlukan bertemu secara fisik kurang tersampaikan dengan baik salah satunya adalah peningkatan kolaborasi antar tim.

Hasil wawancara yang dilakukan kepada salah satu peserta program orientasi secara virtual ini (Dewi) juga hampir memiliki kesamaan dengan yang diungkapkan oleh Moh. Insan di atas. Menurut peserta, virtual orientasi ini cukup menantang karena peserta dituntut untuk saling mengenal satu sama lain tanpa ada pertemuan. Selain itu, perbedaan waktu juga membuat kendala, ada peserta yang berasal dari kawasan Indonesia Timur yang tentunya jam istirahat akan berbeda dengan peserta yang berasal dari kawasan Indonesia Barat. Dewi juga menjelaskan bahwa semakin lama akan terbiasa. Menurut Dewi, program orientasi secara virtual ini tidak mengurangi nilai-nilai orientasi, peserta tetap bisa survive sehingga menambah banyak pengalaman baru karena semua penugasan dibuat secara online. Intinya peserta masih bisa tetap beraktivitas selayaknya normal karena teknologi semakin canggih.

\section{Tabel 3 SWOT Analysis Pelaksanaan Orientasi Karyawan Baru di Masa Pandemi PT Telkom Indonesia}

\begin{tabular}{|c|c|}
\hline Strength & Weakness \\
\hline $\begin{array}{l}\text { a. Perusahaan bisa menghemat biaya yang } \\
\text { dikeluarkan } \\
\text { b. Waktu penyelenggaraan lebih pendek } \\
\text { c. Aman dari COVID-19 } \\
\text { d. Penerapan Teknologi Baru berbasis Virtual } \\
\text { Meeting }\end{array}$ & $\begin{array}{l}\text { a. Kurangnya kontrol dari mentor bagi } \\
\text { peserta induksi } \\
\text { b. Minim experience bagi peserta } \\
\text { c. Perusahaan perlu membuat juknis dan } \\
\text { materi yang lebih lengkap untuk } \\
\text { disampaikan kepada para peserta } \\
\text { d. Koordinasi antar peserta menjadi } \\
\text { terhambat karena perbedaan lokasi dan } \\
\text { waktu }\end{array}$ \\
\hline Opportunities & Threats \\
\hline $\begin{array}{l}\text { a. Perusahaan belajar untuk bisa survive } \\
\text { dengan mempraktekan kecanggihan } \\
\text { teknologi di masa Pandemi COVID-19 } \\
\text { b. Perusahaan bisa melakukan cost saving } \\
\text { untuk masa mendatang }\end{array}$ & $\begin{array}{l}\text { a. Adanya kemungkin engagement dan } \\
\text { komitmen karyawan kurang } \\
\text { b. Kemungkinan peserta akan mudah } \\
\text { membandingkan bentuk induksi dengan } \\
\text { perusahaan lain }\end{array}$ \\
\hline
\end{tabular}


c. Peserta dan Perusahaan dapat meningkatkan soft skill terkait penyelenggaraan virtual meeting c. Adanya kemungkinan fokus peserta akan terganggu dan mencari kesibukan lain ketika program induksi berjalan

Sumber: Olahan data penulis

Saya akan mencoba untuk merangkum hasil wawancara dengan para informan ke dalam tabel analisis SWOT. Kata SWOT singkatan dari Strength, Weakness, Opportunities, dan Threats merupakan teknik perencanaan strategi yang bermanfaat untuk mengevaluasi kekuatan (strength), kelemahan (weakness), peluang (opportunities), dan ancaman (threats) dalam suatu proyek, baik yang sedang berlangsung maupun dalam perencanaan baru. Analisis SWOT disampaikan dalam Tabel 3 di atas.

Menurut Aperian Global, terdapat 10 strategi untuk membuat program orientasi karyawan baru secara virtual berjalan dengan baik dan menyenangkan. Strategi akan dijelaskan sebagai berikut :

- Overprepare for your new employee

Saat kita bekerja di lingkungan virtual, materi akan mudah tercecer. Kita bisa membuat suatu juknis pelaksanaan Program Orientasi secara detail, membuat skala prioritas, dan selalu berpegang pada hasil akhirnya.

- Fill downtime with self-study items

Kita bisa membuat daftar item "belajar mandiri" (dokumen, artikel penting, situs web, informasi pesaing) untuk disampaikan kepada para karyawan saat virtual meeting yang harus diselesaikan.

- Schedule a face-to-face webcam introduction with the team

Kita bisa membuat suatu acara pre Orientasi bagi para karyawan, misal melalui grup whatsapp atau telegram agar mereka mengenal satu sama lain.

- Set up virtual meetings with crucial company figures

Dalam acara virtual meeting, kita bisa mengundang beberapa pejabat tinggi perusahaan untuk memberikan materi.

- Connect them to other virtual colleagues

Kita bisa membagi peserta dalam suatu "break out room" agar mereka dapat berbagi kiat, wawasan, dan strategi, dan juga akan menjadi sumber daya yang berharga bagi satu sama lain di masa mendatang.

- Check-in on them regularly 
Setelah mereka dibagi ke dalam beberapa tim kelompok, kita bisa menjadwalkan pertemuan mereka sesering mungkin dengan memberikan tugas yang penyelesaiannya dilakukan secara kelompok.

- Identify an off-hour mentor

Mentor harus siap dihubungi di luar virtual meeting ketika karyawan atau tim mengalami kesulitan dalam penyelesaian tugas.

- Document is everything

Penting untuk memberikan dokumentasi tertulis kepada karyawan baru tentang segala sesuatu, seperti proses dan prosedur khusus yang berhubungan dengan perusahaan.

- Use your internal experts

Kita bisa mengundang banyak expert dari perusahaan kita untuk menjadi pembicara, dan harus berbeda supaya tidak membosankan.

- Rethink your budget

Kita bisa membuat anggaran untuk makan siang virtual dengan karyawan baru tersebut. Alokasikan setiap peserta dengan sejumlah uang yang dapat mereka gunakan untuk membeli makan siang, dan kemudian kita bisa menyuruh mereka menikmati makan bersama dalam konferensi video.

\section{KESIMPULAN}

Selain berdampak mematikan kehidupan manusia, COVID-19 memiliki potensi mengubah peradaban, baik secara positif maupun negatif. Krisis COVID-19 telah memaksa virtual working menjadi metode utama untuk menjalankan bisnis di dunia modern karena pembatasan sosial. Tak terkecuali perusahaan BUMN plat merah milik pemerintah, yaitu PT Telkom Indonesia. Manajemen dihadapkan pada permasalahan bagaimana cara agar program Induksi dan Orientasi di masa pandemi COVID-19 ini tetap ada karena perusahaan sudah sangat membutuhkan para karyawan baru ini agar bisnis proses tetap berjalan lancar.

Tahapan masa orientasi karyawan baru setelah pandemi COVID-19 sebenarnya hampir sama dengan sebelum pandemi. Yang membedakan hanyalah penundaan aktivitas pembinaan mental yang dilakukan bersama TNI AD serta pelaksanaan in class training dilakukan melalui virtual meeting. Untuk On the Job Training (OJT) dan tahapan Karyawan Dalam Masa Percobaan masih dilaksanakan. Program orientasi secara virtual 
ini tidak mengurangi nilai-nilai orientasi, peserta tetap bisa survive sehingga menambah banyak pengalaman baru karena semua penugasan dibuat secara online. Intinya peserta masih bisa tetap beraktivitas selayaknya normal karena teknologi semakin canggih.

Kelebihan dari program induksi virtual ini adalah (1) perusahaan bisa menghemat biaya yang dikeluarkan; (2) penyelenggaraan waktu acara lebih pendek; (3) aman dari COVID-19 (4) penerapan Teknologi Baru berbasis Virtual Meeting karena pandemi COVID-19 inilah memaksa perusahaan untuk menjadi lebih agile dalam penerapan teknologi baru. Namun program induksi dan orientasi secara virtual ini juga memiliki kekurangan, di antaranya (1) kurangnya kontrol dari mentor; (2) minim experience bagi karyawan karena materi yang seharusnya memerlukan bertemu secara fisik kurang tersampaikan dengan baik salah satunya adalah peningkatan kolaborasi antar tim.

\section{Saran}

1. Bagi peserta

Para peserta sebaiknya harus bisa saling menghormati dan menghargai kendala perbedaan waktu. Komunikasi yang baik antar peserta harus selalu dijalankan agar setiap tugas yang diberikan perusahaan saat program orientasi dapat diselesaikan dengan baik.

2. Bagi perusahaan

Program induksi dan orientasi virtual tidaklah mudah karena antara peserta dan perusahaan hanya bertemu secara virtual. Perusahaan sebaiknya harus overprepare. Saat kita bekerja di lingkungan virtual, materi akan mudah tercecer. Perusahaan bisa membuat suatu petunjuk teknis pelaksanaan Program Orientasi secara detail, membuat skala prioritas, dan selalu memberikan feedback sesegera mungkin pada hasil akhirnya.

\section{DAFTAR PUSTAKA}

Abramo, F., Caye, J., Haen, P., Strack, R. \& Von Der Linden, C. (2013). Creating People Advantage 2013: Lifting HR Practices to the Next Level. The Boston Consulting Group. Retrieved from https://imagesrc.bcg.com/Images/Creating_People_Advantage_Oct_2013_tcm991995.pdf

Ahuja, M. K., \& Carley, K. M. (1999). Network structure in virtual organizations. Organization Science, 10(6), 741-757. 
Anderson, B. (2020). 7 Steps to Creating a Virtual Employee Onboarding Program. Linkedin. Retrieved from https://business.linkedin.com/talentsolutions/blog/onboarding/2020/steps-tocreating-virtual-onboarding-program.

Aperian Global. (2020). 10 Ways to Instantly Improve Virtual Onboarding. Retrieved from https://www.aperianglobal.com/10-ways-to-instantly-improve-virtualonboarding/

Bauer, T. N. (2013). Onboarding New Employees: Maximizing Success. SHRM. Retrieved from https://www.shrm.org/hr-today/trends-andforecasting/specialreports-and-expert-views/Documents/Onboarding-NewEmployees.pdf

Bogdan, Robert C. \& Taylor, S.J. (1973). Introduction to Qualitative Research Methods A Phenomenological Approach to the Social Sciences. New York : John Wiley \& Sons.

Brynjolfsson, E., Horton, J. J., Ozimek, A., Rock, D., Sharma, G., \& TuYe, H. Y. (2020). Covid-19 and remote work: An early look at us data (No. w27344). National Bureau of Economic Research. Retrieved from https://johnjosephhorton.com/papers/remote_work.pdf

Cascio, W. F. (2000). Managing a virtual workplace. Academy of Management Perspectives, 14(3), 81-90.

Elset, J. I. (2018). Organizational socialization in remote-working companies: enhancing company onboarding through gamification (Doctoral dissertation). Retrieved from https://repositorio.iscteiul.pt/bitstream/10071/18803/1/master_john_iver_elset.pd $\underline{f}$

Flanagin, A. J., \& Waldeck, J. H. (2004). Technology use and organizational newcomer socialization. The Journal of Business Communication, 41(2), 137-165.

Fulk, J., \& DeSanctis, G. (1995). Electronic communication and changing organizational forms. Organization Science, 6(4), 337-349.

Gralinski, Lisa E.; Menachery, Vineet D. (2020). Return of the Coronavirus: 2019nCoV. Viruses 12(2): 135. https://doi.org/10.3390/v12020135

Gruman, J. A., \& Saks, A. M. (2018). E-socialization: The problems and the promise of socializing newcomers in the digital age. In J. H. Dulebohn \& D. L. Stone, The brave new world of eHRM 2.0 (p. 111-139). IAP Information Age Publishing.

Nugraha, Safri et.al (2005). Hukum Administrasi Negara. (Cet.1). Jakarta: Badan Penerbitan Fakultas Hukum Universitas Indonesia.

Pavlina, Kaitlyn. (2020). Assessing best practices for the virtual onboarding of new hires in the technology industry. Theses and Dissertations. 1168. https://digitalcommons.pepperdine.edu/etd/1168

PT Telkom Indonesia. (2020). HCM Policy Compilation 2020. Hal 23. 